\title{
FAKTOR YANG BERHUBUNGAN DENGAN KEJADIAN PENYAKIT MALARIA (STUDI LITERATUR)
}

\author{
Factors Related To The Event Of Malaria Disease (Study Of Literature) \\ Nur Muh.Arief ${ }^{1}$, Muh. Ikbal Arif ${ }^{2}$, Erlani ${ }^{3}$ \\ ${ }^{1}$ Mahasiswa Program Studi Sanitasi Lingkungan, Poltekkes Kemenkes Makassar \\ ${ }^{2}$ Dosen Poltekkes Kemenkes Makassar \\ *nurmuharief@gmail.com, 082348323029
}

\begin{abstract}
Malaria is an infectious disease caused by the Plasmodium parasite which can be characterized by fever, hepatosplenomegaly and anemia. Plasmodium lives and reproduces in human red blood cells. This disease is naturally transmitted through the bite of female Anopheles nyanmuk. Endemic malaria in several regions of Indonesia. The most common malaria parasites found are Plasmodium Vivax, Plasmodium Falcifarum, or a mixture of the two. Meanwhile, Plasmodium Ovale and Plasmodium Malariae have been found only in Sulawesi and Irian Jaya. This study aims to determine the factors associated with the incidence of malaria. This type of research is a literature study, namely by collecting data in the form of secondary data obtained from literature, books, and the results of previous studies that examine the relationship between independent and dependent variables. Based on the 6 journals of research studies with four variables studied, it shows that there are factors that are related to the incidence of malaria, namely the use of mosquito nets, the presence of standing water, public knowledge but lighting does not indicate a relationship with the incidence of malaria. To eradicate mosquito nests, namely cleaning stagnant water, brackish water, swamps and coastal lagoons from larvae and moss, as well as cleaning vegetation / bushes around the house which is a breeding place for Anopheles spp.
\end{abstract}

Keywords: lighting, use of mosquito nets, public knowledge

\section{ABSTRAK}

Malaria adalah penyakit infeksi yang disebabkan oleh parasit Plasmodium yang dapat ditandai dengan demam hepatosplenomegali dan anemia. Plasmodium hidup dan berkembang biak dalam sel darah merah manusia. Penyakit ini secara alami ditularkan melalui gigitan nyanmuk Anopheles betina. Penyakit malaria endemis di beberapa wilayah Indonesia. Parasit malaria yang terbanyak ditemukan adalah Plasmodium Vivax, Plasmodium Falcifarum, atau campuran dari keduanya. Sementara Plasmodium Ovale dan Plasmodium Malariae pernah ditemukan hanya di Sulawesi dan Irian Jaya. Penelitian ini bertujuan untuk mengetahui faktor - faktor yang berhubungan dengan kejadian penyakit malaria. Jenis penelitian ini adalah studi literatur, yaitu dengan mengumpulkan data berupa data sekunder yang diperoleh dari literatur - literatur, buku - buku, dan hasil penelitian sebelumnya yang mengkaji hubungan variabel bebas dan variabel terikat. Berdasarkan dari 6 jurnal studi penelitian dengan empat variabel yang dikaji menunjukkan adanya faktor - faktor yang berhubungan dengan kejadian penyakit malaria yaitu penggunaan kelambu, keberadaan genangan air, pengetahuan masyarakat tetapi pencahayaan tidak menunjukkan adanya hubungan dengan kejadian penyakit malaria. Melakukan pemberantasan sarang nyamuk yaitu pembersihan air tergenang, air payau, rawa dan lagoon-lagoon ditepi pantai dari jentik dan lumut, serta membersihkan vegetasi / semak-semak disekitar rumah yang merupakan tempat perindukan nyamuk Anopheles spp.

Kata Kunci : pencahayaan, penggunaan kelambu, pengetahuan Masyarakat

\section{PENDAHULUAN}

Malaria yaitu salah satu penyakit infeksi yang disebabkan oleh parasite Plasmodium melalui gigitan nyamuk anopheles betina. Pada tubuh manusia, parasit membelah diri dan bertambah banyak di dalam hati dan kemudian menginfeksi sel darah merah. Malaria pada manusia dapat disebabkan oleh $P$. malariae, $P$. vivax, $P$. ovale dan $P$. Falciparum, merupakan yang paling berbahaya dan dapat mengancam nyawa. (Arsin, .2012)

Data dan informasi profil Provinsi Sulawesi selatan tahun (2018), jumlah sediaan darah malaria positif sebanyak 1.285 orang dari 13.751 orang, sehingga angka Annual Parasite Insidence (API) yaitu 0,10 per-1000 penduduk tahun 2015, dengan mengalami kenaikan disetiap tahun yakni 0,12 per- 1000 penduduk di tahun 2016, 0,14 per-1000 penduduk di tahun 2017, dan 0,15 per-1000 penduduk di tahun 2018.

Berdasarkan keadaan diatas maka peneliti tertarik untuk meneliti tentang kejadian malaria. Secara pandangan khusus terkait penelitian yang telah dilaksanakan di jurusan kesehatan lingkungan tersendiri belum adanya dibahas mengenai kejadian malaria maka dari itu ketertarikan peniliti untuk meneliti tentang faktor faktor yang berhubungan dengan kejadian penyakit malaria.

Secara garis besar telah di jelaskan faktor yang berhubungan dengan kejadian malaria namun batasan yang akan di teliti oleh peneliti terkait variable yang akan di laksanakan ialah mengetahui hubungan pencahayaan, penggunaan kelambu ketika tidur, keberadaan genangan air di sekitar rumah responden, serta pengetahuan masyarakat dengan kejadian penyakit Malaria.

\section{METODE \\ Jenis Penelitian}

Penelitian ini bersifat Metode Kepustakaan (Library Method) Penelitian Kepustakaan merupakan metode yang digunakan dalam pencarian data, atau cara pengamatan (bentuk observasi) secara mendalam terhadap tema yang diteliti untuk menemukan 'jawaban sementara' dari masalah yang ditemukan di awal sebelum penelitian ditindaklanjuti. 


\section{Metode Pengumpulan Data}

Pengambilan data dilakukan melalui studi pustaka dengan melakukan penelusuran hasil publikasi ilmiah dengan rentan tahun 2015 - 2020 dengan menggunakan online library. Hasil penelusuran kemudian dianalisis dan disimpulkan.

\section{Sumber Data}

Data Sekunder

Data sekunder diperoleh dengan mengumpulkan data yang bersumber dari literatur - literatur, bahan kuliah, buku-buku dan hasil penelitian lainnya yang berhubungan dengan objek peneliti.

\section{Analisis Data dan Penyajian Data}

Penyajian data untuk studi literatur, disajikan secara tabel dan narasi.

\section{HASIL DAN PEMBAHASAN}

1. Hubungan Pencahayaan Dengan Kejadian Penyakit Malaria

Tabel 1

\begin{tabular}{|c|c|c|c|c|c|c|c|}
\hline \multirow{2}{*}{$\begin{array}{l}\text { Pencahaya } \\
\text { an }\end{array}$} & \multicolumn{2}{|c|}{ Kasus } & \multicolumn{2}{|c|}{ Kontrol } & \multirow{2}{*}{$\begin{array}{l}\text { P } \\
\text { Valu } \\
\text { e }\end{array}$} & \multirow{2}{*}{ OR } & \multirow{2}{*}{$\begin{array}{l}95 \% \\
\mathrm{Cl}\end{array}$} \\
\hline & $\mathrm{F}$ & $\%$ & $\mathrm{~F}$ & $\%$ & & & \\
\hline $\begin{array}{l}\text { Tidak } \\
\text { Memenuhi } \\
\text { Syarat }\end{array}$ & 3 & 8,1 & 4 & $\begin{array}{l}10 \\
8\end{array}$ & $\begin{array}{l}1,00 \\
0\end{array}$ & $\begin{array}{l}0,72 \\
8\end{array}$ & $\begin{array}{l}0,15 \\
1-\end{array}$ \\
\hline $\begin{array}{l}\text { Memenuhi } \\
\text { Syarat }\end{array}$ & $\begin{array}{l}3 \\
4\end{array}$ & $\begin{array}{l}91 \\
9\end{array}$ & $\begin{array}{l}3 \\
3\end{array}$ & $\begin{array}{l}89 \\
2\end{array}$ & & & $\begin{array}{l}3,50 \\
5\end{array}$ \\
\hline Jumlah & $\begin{array}{l}3 \\
7\end{array}$ & 100 & $\begin{array}{l}3 \\
7\end{array}$ & 100 & & & \\
\hline
\end{tabular}

Sumber : Pratiwi lka Novianti, Tri Joko, Nikie Astorina Yunitas Dewanti 2016 (hubungan faktor lingkungan fisik dan prilaku penghuni rumah dengan kejadian penyakit malaria di wilayah kerja puskesmas kokap II, kabupaten kulom progo, daerah istimewah yogyakarta.

Berdasarkan Tabel 1 menunjukkan bahwa berdasarkan hasil uji chi squre didapatkan nilai $\mathrm{OR}=0,728$. Karena nilai $\mathrm{P}$ Value sebesar 1,000 yang artinya tidak terdapat hubungan intensitas cahaya dengan kejadian malaria. Maka dilihat dari nilai $\mathrm{OR}=0,728$ atau $<1$ yang artinya masyarakat lebih protektif dengan kejadian penyakit malaria.
Tabel 2

\begin{tabular}{cllllllll}
\hline \multirow{2}{*}{$\begin{array}{c}\text { Pencahayaa } \\
\mathbf{n}\end{array}$} & \multicolumn{4}{l}{ Kasus } & Kontrol & Jumlah & $\begin{array}{l}\text { P } \\
\text { (Sig) }\end{array}$ \\
\cline { 2 - 5 } & F & $\%$ & F & $\%$ & F & $\%$ & \\
>60 Lux & 2 & 42, & 2 & 40, & 5 & 41, & $\begin{array}{l}0,85 \\
8\end{array}$ \\
$<60$ Lux & 3 & 57, & 3 & 59, & 7 & 58, &
\end{tabular}

Sumber : Hermanto Putra, Muhammad Badiran, Arifah Devi Fitriani 2020 (faktor yang mempengaruhi kejadian malaria di wilayah kerja puskesmas leuser kabupaten aceh tenggara provinsi aceh.

Berdasarkan Tabel 2 menunjukkan bahwa berdasarkan hasil uji statistik chi square didapatkan nilai $p$ value $=0,858 \quad(p>0,05)$. Dengan demikianpenelitian ini adalah tidak ada hubungan dengan kejadian penyakit malaria diwilayah kerja puskesmas leuser kabupaten aceh tenggara provinsi aceh tahun 2019.

Pencahayaan, tidak ada hubungan yang dihasilan dari 2 jurnal berdasarkan tabel 1 dan tabel 2 diatas.

Rumah yang sehat memerlukan cahaya yang cukup, tidak kuran dan tidak terlalu banyak. Kurangnya cahaya yang masuk ke dalam ruangan rumah merupakan tempat yang baik untuk hidup dan berkembangnya bibit bibit penyakit seperti nyamuk Anpheles. Sebaliknya jika berlebihan cahaya didalam rumah akan menyebabkan silau dan akhirnya merusak mata

\section{Hubungan Penggunaan Kelambu Dengan Kejadian Penyakit Malaria}

\section{Tabel 3}

\begin{tabular}{lllll}
\hline $\begin{array}{l}\text { Kebiasaan } \\
\text { Menggunakan } \\
\text { Kelambu }\end{array}$ & $\begin{array}{l}\text { Kejadian } \\
\text { Malaria }\end{array}$ & $\begin{array}{l}\boldsymbol{p} \text { - } \\
\text { valu } \\
\boldsymbol{e}\end{array}$ & $\begin{array}{l}\text { Kas } \\
\text { us }\end{array}$ & $\begin{array}{l}\text { OR } \\
(95 \% \mathrm{Cl})\end{array}$ \\
\hline Tidak & 67 & 37 & $\begin{array}{l}0,00 \\
01\end{array}$ & $\begin{array}{l}7,8 \\
(3,42- \\
17,97)\end{array}$ \\
\hline Ya & 9 & 39 & & \\
\hline
\end{tabular}

Jumlah

$76 \quad 76$

Sumber : Harmendo 2015 (Faktor risiko kejadian malaria di wilayah kerja puskesmas kenanga kecamatan sungailiat kabupaten bangka.

Berdasarkan Tabel 3 menunjukkan bahwa berdasarkan hasi uji chi square menunjukkan ada hubungan penggunaan kelambu dengan kejadian malaria dengan perhitungan $\mathrm{OR}=7,8$ dengan $\mathrm{Cl}$ (Confidence Interval) $95 \%=3,42-$ 17,97 dan didukung oleh nilai $p$ value $=0,0001$. Hasil ini dapat diinterprestasikan bahwa orang yang tidak menggunakan kelambu waktu tidur punya risiko terkena malaria 7,8 kali lebih besar dari orang yang tidur menggunakan kelambu. 
Tabel 4

\begin{tabular}{|c|c|c|c|c|c|c|}
\hline \multirow{3}{*}{$\begin{array}{l}\text { Penggunaan } \\
\text { Kelambu }\end{array}$} & \multicolumn{4}{|c|}{ Kejadian Malaria } & \multirow{3}{*}{$\begin{array}{l}p- \\
\text { value }\end{array}$} & \multirow{3}{*}{$\begin{array}{l}\text { OR } \\
(95 \% \mathrm{Cl}\end{array}$} \\
\hline & \multicolumn{2}{|c|}{ Kasus } & \multicolumn{2}{|c|}{ Kontrol } & & \\
\hline & $\mathrm{n}$ & $\%$ & $\mathrm{n}$ & $\%$ & & \\
\hline Tidak & 20 & 29,4 & 25 & 36,8 & 0,0061 & $\begin{array}{l}2,777 \\
(1,2966 \\
- \\
5,9510)\end{array}$ \\
\hline
\end{tabular}

Sumber : Budi Junarman Sinaga 2018 (Pengaruh faktor Eksternal dan Internal Terhadap kejadian Malaria Endemik dengan Analisis Spesial di Kabupaten Batu Bara Tahun 2017.

Berdasarkan Tabel 4 menunjukkan adanya hubungan penggunaan kelambu dengan kejadian penyakit Malaria menunjukkan nilai OR sebesar 2,777 dengan 95\% Cl 1,2966 - 5,9510.

Dengan demikian, dapat dijelaskan bahwa terjadinya malaria 3 kali lebih besar disebabkan oleh responden yang menggunakan kelambu dibandingkan responden yang tidak menggunakan kelambu.

Pemakaian kelambu adalah salah satu dari upaya pencegahan penularan penyakit malaria. Menggunakan kelambu secara teratur pada waktu malam hari dapat mengurangi kejadian malari.

\section{Hubungan Keberadaan Genangan Air dengan Kejadian Penyakit Malaria}

Tabel 5

\begin{tabular}{lllll}
\hline $\begin{array}{l}\text { Keberdaan } \\
\text { Genangan } \\
\text { Air }\end{array}$ & \multicolumn{2}{l}{ Kejadian Malaria } & $\begin{array}{l}\text { p- } \\
\text { value }\end{array}$ & $\begin{array}{l}\text { OR } \\
(\mathbf{9 5 \%} \% \mathbf{C l})\end{array}$ \\
\cline { 5 - 5 } Ada & 46 & 35 & 0,001 & $\begin{array}{l}3,1 \\
(1,61- \\
6,07)\end{array}$ \\
\hline Tidak & 30 & 51 & & \\
\hline
\end{tabular}

Jumlah $\quad 76 \quad 76$

Sumber : Harmendo 2015 (Faktor risiko kejadian malaria di wilayah kerja puskesmas kenanga kecamatan sungailiat kabupaten bangka.

Berdasarkan Tabel 5 menunjukkan ada hubungan keberadaan genangan air dengan kejadian penyakit Malaria. Hasil perhitungan OR didapat hasil $\mathrm{OR}=3,1$ dengan Confidence Interval $(\mathrm{Cl}) 95 \%=1,61-6,07$ dan diperkuat dengan hasil $p$ value $=0,001$.

Hasil ini dapat diinterprestasikan bahwa disekeliling rumahnya terdapat genangan air punya risiko terkena malaria 3,1 kali lebih besar dari orang tidak terdapat genangan air di sekitar rumah mereka.

Hasil penelitian memperlihatkan nilai Chi-Square sebesar 7,531 dengan $p=0,006<$ 0.05 . Pengujian cross tab yang dilakukan untuk mengetahui adanya hubungan faktor keberadaan genangan air dengan kejadian penyakit malaria untuk jurnal sumber :

Abner Fritz Watofa, Adi Heru Husodo, Sudarmadji dan Onny Setiani, 2017 (Risiko Lingkungan Fisik Terhadap Kejadian Malaria Di Wilayah Danau Sentani, Kabupaten Jayapura, Provinsi Papua).

Berdasarkan hasil perhitungan tersebut dapat diketahui kekuatan hubungan dengan faktor keberadaan genangan air dengan kejadian penyakit malaria sebesar $89 \%$ oleh karna itu, dapat dijelaskan bahwa faktor keberadaan genangan air sangat bermakna dengan kejadian penyakit malaria di wilayah Danau Sentani.

Tabel 6

\begin{tabular}{|c|c|c|c|c|c|c|}
\hline \multirow{3}{*}{$\begin{array}{l}\text { Genangan } \\
\text { Air }\end{array}$} & \multicolumn{4}{|c|}{ Kejadian Malaria } & \multirow{3}{*}{$\begin{array}{l}p- \\
\text { value }\end{array}$} & \multirow{3}{*}{$\begin{array}{l}\text { OR } \\
(95 \% \mathrm{Cl})\end{array}$} \\
\hline & \multicolumn{2}{|c|}{ Kasus } & \multicolumn{2}{|c|}{ Kontrol } & & \\
\hline & $\mathrm{N}$ & $\%$ & $\mathrm{n}$ & $\%$ & & \\
\hline Ada & 26 & 38,2 & 23 & 33,8 & 0,013 & $\begin{array}{l}2,555 \\
(1,1825 \\
- \\
5,5229)\end{array}$ \\
\hline
\end{tabular}

$\begin{array}{lllll}\text { Tidak } & 9 & 13,2 & 10 & 14,7\end{array}$

Sumber : Budi Junarman Sinaga 2017 (Pengaruh faktor Eksternal dan Internal Terhadap kejadian Malaria Endemik dengan Analisis Spesial di Kabupaten Batu Bara Tahun 2017.

Berdasarkan Tabel 6 menujukkan hasil adanya hubungan dengan kejadian malaria di kabupaten batubara tahun 2017 karena memiliki nilai OR sebeasar 2,555 dengan $95 \%$ Cl 1,18255,5229.

Hasil ini menjelaskan bahwa terjadinya malaria 3 kali lebih besar disebabkan adanya genangan air dibandingkan dengan tidak adanya genangan air, serta di perkuat dengan nilai $p<$ 0,05 yaitu sebesar 0,013 .

\section{Tabel 7}

\begin{tabular}{|c|c|c|c|c|c|c|c|}
\hline \multirow{3}{*}{$\begin{array}{l}\text { Genangan } \\
\text { Air }\end{array}$} & \multicolumn{4}{|c|}{ Kejadian Malaria } & \multirow{2}{*}{\multicolumn{2}{|c|}{ Jumlah }} & \multirow{3}{*}{$\begin{array}{l}P \\
\text { (Sig) }\end{array}$} \\
\hline & \multicolumn{2}{|c|}{ Kasus } & \multicolumn{2}{|c|}{ Kontrol } & & & \\
\hline & $\mathrm{F}$ & $\%$ & $f$ & $\%$ & $f$ & $\%$ & \\
\hline Terdapat & 40 & 62,5 & 20 & 31,5 & 60 & 46,9 & 0,001 \\
\hline $\begin{array}{l}\text { Tidak } \\
\text { Terdapat }\end{array}$ & 25 & 37,5 & 44 & 68,8 & 68 & 53,1 & \\
\hline
\end{tabular}

Sumber : Hermanto Putra, Muhammad Badiran, Arifah Devi Fitriani 2020. (Faktoryang mempengaruhi kejadian malaroa di wilayah kerja puskesmas leuser kabupaten aceh tenggara provinsi aceh) Berdasarkan Tabel 7 menunjukkan hasil menurut analisa chi square didapat nilai $p$ value $=0,001(p<0,05)$. Dengan demikian maka dalam penelitian ini adanya pengaruh faktor genangan air dengan kejadian penyakit malaria di wilayah kerja puskesmas leuser kabupaten aceh tenggara provinsi aceh tahun 2019. 
Kategori menderita cenderung terdapat genangan air sebanyak 40 responden $(62,5 \%)$. Kategori tidak menderita cenderung tidak terdapat genangan air sebanyak 44 respoden $(68,8 \%)$

Genangan air merupakan bionomik (Tempat Hidup Nyamuk) yang berpotensi sebagai faktor yang berhubungan dengan kejadian penyakit malaria, dikarenakan khususnya nyamuk sp.Anhopeles yang menyukai jenis air payau digunakan sebagai tempat bertelur dan tempat berkembangnya larva nyamuk.

Genangan air tersebut bisa merupakan danau, aliran air, kolam, bendungan, saluran irigasi air bebatuan, tangki septik, kaleng bekas dan lain sebagainya yang memiliki salinitas (jumlah garam terlarut dalam air) diantara 500 ppm sampai 30.000 ppm (0,5 ppt 30 ppt). Air hutan bakau atau air rawa biasanya juga termasuk jenis air payau.

\section{Hubungan Pengetahuan Masyarakat Dengan Kejadian Penyakit Malaria}

\begin{tabular}{|c|c|c|c|c|}
\hline \multirow[b]{2}{*}{ Pengetahuan } & \multicolumn{2}{|c|}{ Kejadian Malaria } & \multirow{2}{*}{$\begin{array}{l}p \text { - } \\
\text { value }\end{array}$} & \multirow{2}{*}{$\begin{array}{l}\text { OR } \\
\text { (95\% } \\
\text { Cl) }\end{array}$} \\
\hline & Kasus & Kontrol & & \\
\hline Ya & 52 & 24 & 0,0001 & $\begin{array}{l}47 \\
(2,37 \\
- \\
9,30)\end{array}$ \\
\hline Tidak & 24 & 52 & & \\
\hline Jumlah & 76 & 76 & & \\
\hline
\end{tabular}

Sumber : : Harmendo 2015 (Faktor risiko kejadian

malaria di wilayah kerja puskesmas kenanga

kecamatan sungailiat kabupaten bangka.

Pada Tabel 8 menunjukkan hasil uji chisquare ada hubungan pengetahuan masyarakat dengan kejadian penyakit malaria. Perhitungan OR didapat hasil $\mathrm{OR}=4,7$ dengan confidence interval $(\mathrm{Cl}) 95 \%=2,37$ 9,30.

Hasil ini dapat diinterprestasikan bahwa orang yang punya kebiasaan keluar rumah malam hari punya risiko tekena malaria 4,7 kali lebih besar dibanding orang yang tidak punya kebiasaan keluar rumah malam hari, dan diperkuat dengan nilai $p$-value $(p=0,0001)$
Tabel 9

\begin{tabular}{|c|c|c|c|c|}
\hline \multicolumn{5}{|c|}{ Derajat Infeksi } \\
\hline & & Ringan & Sedang & Tota \\
\hline \multirow{2}{*}{ Pengetahuan } & Sedang & 14 & 1 & 15 \\
\hline & Baik & 35 & 0 & 35 \\
\hline Total & & 49 & 1 & 50 \\
\hline \multicolumn{5}{|c|}{$\begin{array}{l}\text { Sumber : Wage Nurmaulina, Betta Kurniawan, Hanif } \\
\text { Fakhruddin. } 2018 \text { (Hubungan Pengetahuan, Sikap dan } \\
\text { Perilaku Penderita Malaria Falciparum Dengan Derajat } \\
\text { Infeksi di Wilayah Kerja Puskesmas Hanura } \\
\text { Kecamatan Teluk Pandan Kabupaten Pesawaran } \\
\text { Provinsi Lampung) }\end{array}$} \\
\hline
\end{tabular}

Tabel 9 memperlihatkan distribusi hubungan pengetahuan dengan derajat infeksi malaria falciparum pada tahun 2016. Dari tabel tersebut dapat diketahui, dari 50 sampel yang berpengetahuan sedang dengan derajat infeksi sedang terdapat 1 responden dan yang berpengetahuan baik dengan derajat infeksi ringan terdapat 35 responden.

Berdasarkan hasil analisis Fisher' $s$ exact test di dapatkan $p=0,30$ ( $p$-value $>0,05$ ). Hal ini berarti tidak ada hubungan yang signifikan antara pengetahuan dengan derajat infeksi diwilayah kerja puskesmas Hanura.

Berdasarkan jurnal Hubungan Pengetahuan, Sikap dan Perilaku Penderita Malaria Falciparum Dengan Derajat Infeksi di Wilayah Kerja Puskesmas Hanura Kecamatan Teluk Pandan Kabupaten Pesawaran Provinsi Lampung (Wage Nurmaulina, Betta Kurniawan, Hanif Fakhruddin, 2018).

Hasil peneliti menunjukkan tidak terdapat hubungan dengan pengetahuan dengan kejadian penyakit malaria Falciparum, tetapi sebagian besar responden memiliki pengetahuan yang baik hal ini dimungkinkan terjadi karena sering dilakukan penyuluhan oleh tenaga kesehatan atau instansi lain.

Dalam jenis penelitian diatas yang dibahas mulai dari hubungan pencahayaan, penggunaan kelambu, keberadaan genangan air, serta pengetahuan masyarakat dengan kejadian penyakit malaria dapat dibedakan berdasarkan hasil penelitian yang didapatkan oleh sipeneliti, untuk cross sectional nilai yang dicantumkan dalam hasil ialah nilai $p$-value, sedangkan case control mencantumkan nilai OR Nilai OR yang dihasilkan apabila bernilai 0,5 atau $<1$ berarti masyarakat di wilayah tersebut masih taraf protektif dengan kejadian penyakit malaria.

Apabila nilai OR yang dihasilkan 1 memilki artian ada hubungan tetapi lemah namun, ketika nilai OR yang dihasilkan 2 atau lebih bahkan hingga 100 nilai OR itu berarti ada hubungan sangat kuat dengan kejadian penyakit Malaria di wilayah tersebut. 
Jurnal Sulolipu : Media Komunikasi Sivitas Akademika dan Masyarakat

Vol. 20 No.2 2020

e-issn : 2622-6960, p-issn : 0854-624X

\section{KESIMPULAN}

1. Tidak terdapat hubungan pencahayaan dengan kejadian penyakit Malaria. Berdasarkan Tabel 1 hasil $\mathrm{OR}=0,728$ dan Tabel 2 nilai $p$ value $=0,858(p>0,05)$.

2. Terdapat hubungan penggunaan kelambu dengan kejadian penyakit Malaria. Berdasarkan Tabel 3 hasil $\mathrm{OR}=7,8$ dan Tabel 4 hasil nilai $\mathrm{OR}=2,777$.

3. Terdapat hubungan keberadaan genangan air dengan kejadian penyakit Malaria. Berdasarkan Tabel 5 hasil $\mathrm{OR}=3,1$ dan Tabel 6 nilai $\mathrm{OR}=2,555$ dan Tabel 7 nilai $p$ value $=0,001 \quad(\mathrm{p}<0,05)$.

4 Terdapat hubungan pengetahuan masyarakat dengan kejadian penyakit Malaria. Berdasarkan Tabel 8 hasil OR=4,7 SARAN dan Tabel 9 nilai $p=0,30$ ( $p$-value $>0,05)$.

1. Untuk peneliti studi literatur selanjutnya, mempersiapkan literatur lebih memadai dan bervariasi agar topik yang diangkat dapat dibahas lebih mendalam. Serta peneliti menyiapkan kondisi fisik dan mental dalam melakukan pengerjaan studi literatur karena menghabiskan waktu lama didepan monitor, terutama menjaga kesehatan mata.

2. banyak faktor yang berhubungan dengan malaria. Studi literatur ini diharapkan dapat menjadi rujukan untuk penelitian selanjutnya.

3. Untuk instansi kesehatan ataupun pengelolah suatu lembaga / instansi agar dapat memberikan edukasi berupa penyuluhan secara mendasar atau pemicuan terhadap pentingnya menjaga personal hygiene untuk mencegah terjadinya penyakit malaria.

4. Untuk masyarakat, agar lebih memperhatikan kebersihan diri / personal hygiene guna mencegah terjadinya penyakit malaria.

\section{DAFTAR PUSTAKA}

Arsin. A.A.. 2012. Malaria di Indonesia. Masagena Press. Makassar.

Atikoh. I.N.. 2015. Faktor yang Berhubungan dengan Kejadian Malaria di Desa Selakambangan Kecamatan Kaligondang Kabupaten Purbalingga Tahun 2014. Skripsi. Peminatan Kesehatan Lingkungan Universitas Islam Negeri Syarif Hidayatullah. Jakarta.

Babba, Ikrayama. 2008. Faktor-Faktor Risiko yang Mempengaruhi Kejadian Malaria. Tesis. Program Pascasarjana Universitas Diponegoro. Semarang.

Fitriany. J. dan Sabiq. A.. 2018. Malaria. Jurnal Averrous. 4 (2).

Friskarini. K.. dan Ariati. J.. 2017. Pengetahuan dan Sikap Masyarakat Terhadap Penggunaan Kelambu Berinsektisida Long Lasting Insecricidal Nets (LLINS) Di Kecamatan Mariat, Kabupaten Sorong, Provinsi Papua Barang. Jurnal Ekologi Kesehatan. 16 (1): 18 - 26.

Hakim. L.. 2011. Malaria: Epidemiolgi dan Diagnosis. Aspirator. 3 (2): 107 - 116.

Hanida. S.F.. 2018. Potensi Tinggi Faktor Lingkungan Fisik dan Biologis Terjadinya Penularan Malaria di Wilayah Kerja Puskesmas Pandean Trenggalek. Jurnal Kesehatan Lingkungan. 10 (1): 82 - 91.

Kurniawan. J..2008. Analisis Faktor Risiko lingkungan dan Perilaku Penduduk Terhadap Kejadian Malaria Di Kabupaten Asmat Tahun 2008. Tesis. Jurusan Kesehatan Lingkungan Universitas Diponegoro. Semarang.

Manumpa. S.. 2016. Pengaruh Faktor Demografi dan Riwayat Malaria Terhadap Kejadian Malaria. Jurnal Berkala Epidemiologi. 4 (3): 338 - 348.

Natalia. T.N.. 2008. Malaria Falcifarum Di RSUP Manado Prof.Dr.R.D.Kandou, Sulawesi Utara Diagnosa Dini dan Penanganannya. Majalah Kedokteran Tropis Indonesia. 19 (3).

Pamela. A.A.. 2009. Hubungan Kondisi Fisik Rumah dan Lingkungan Sekitar Rumah dengan Kejadian Malaria di Desa Ketosari Kecamatan Bener Kabupaten Purworejo. Skripsi. Program Studi Kesehatan Masyarakat Universitas Muhammadiyah. Surakarta.

Purwanto. D.S.. dan Ottay. R.I.. 2011. Profil Penyakit Malaria pada Penderita Rawat Inap Di Rumah Sakit Umum Daerah Kota Bitung. Jurnal Biomedik. 3 (3): 172 - 178.

Rahayu. N.. Sulasmi. S.. dan Suryatinah. Y.. 2016. Efektivitas Aplikasi Kelambu Berinsektidsida (Long Lasting Insecticide Net) Program Pengendalian Vektor Daerah Endemis Malaria Di Kalimantan Selatan. Laporan Akhir. Balai Penelitian dan Pengembangan Kesehatan Kementerian Kesehatan RI. Kalimantan Selatan.

Republik Indonesia. 2011. Epidemiologi Malaria Di Indonesia. Buletin Jendela Data dan Informasi Kesehatan. Kementerian Kesehatan. Jakarta.

Republik Indonesia. 2011. Permenkes Nomor 1077 Tahun 2011. Kementerian Kesehatan Republik Indonesia. Jakarta. 
Jurnal Sulolipu : Media Komunikasi Sivitas Akademika dan Masyarakat

Vol. 20 No.2 2020

e-issn : 2622-6960, p-issn : 0854-624X

Republik Indonesia. 2014. Profil Kesehatan Indonesia Tahun 2014. Kementerian Kesehatan Republik Indonesia. Jakarta.

Republik Indonesia. 2017. Profil Kesehatan Indonesia Tahun 2017. Kementerian Kesehatan Republik Indonesia. Jakarta.

Republik Indonesia. 2018. Data dan Informasi Profil Kesehatan Indonesia. Kementerian Kesehatan Republik Indonesia. Jakarta.

Republik Indonesia. 2018. Hasil Utama Riskesdas 2018. Kementerian Kesehatan Republik Indonesia. Jakarta.

Sinaga. dan Junarman. B.. 2018. Pengaruh Faktor Eksternal dan Internal Terhadap Kejadian Malaria Endemik dengan Analisis Spasial di Kabupaten Batu Bara Tahun 2017. Tesis. Program Studi S2 IImu Kesehatan Masyarakat Universitas Sumatera Utara. Medan.

Noviarti, P. I., Joko, T., \& Dewanti, N. A. (2016). Hubungan Faktor Lingkungan Fisik Dan Perilaku Penghuni Rumah Dengan Kejadian Penyakit Malaria Di Wilayah Kerja Puskesmas Kokap li, Kabupaten Kulon Progo, Daerah Istimewah Yogyakarta.

Nurmaulina, W., Kurniawan, B., \& Fakhruddin, H. (2018). Hubungan Pengetahuan, Sikap dan Prilaku Penderita Malaria Falciparum Dengan Derajat Infeksi di Wilayah Kerja Puskesmas Hanura Kecamatan Teluk Pandan Kabupaten Pesawaran Provinsi Lampung.

Putra, H., Badiran, M., \& Fitriani, A. D. (2020). Faktor Yang Mempengaruhi Kejadian Malaria Di Wilayah Kerja Puskesmas Leuser Kabupaten Aceh Tenggara Provinsi Aceh.

Watofa, A. F., Husodo, A. H., Sudarmadji, \& Setiani, O. (2017'). Resiko lingkungan fisik terhadap kejadian malaria di wilayah danau sentani, kabupaten jayapura, provinsi papua.

Harmendo. (2015). Faktor resiko kejadian malaria di wilayah kerja puskesmas kenanga kecamatan sungailiat kabupaten bangka. Tesis .

Sinaga, B. J. (2017). Pengaruh faktor eksternal dan internal terhadap kejadian malaria endemik dengan analisis spasialis di kabupaten batu bara tahun 2017. Tesis 